\title{
ROBERT WOODS BLISS, 1875-1962
}

\author{
SAMUEL K. LothroP
}

CEW MEN of our century could look back $F$ on such varied interests and activities as Robert Woods Bliss. Others have written of his 33 years as a professional diplomat and of his subsequent service as Special Assistant to the Secretary of State. Probably no complete record exists of the various boards and commissions for which he worked nor of the time, devotion, and understanding he gave to local and community problems. It is, however, as patrons of the arts that both he and his wife, Mildred, will be best remembered. Their interests were not confined to their own collections, which consisted of the material arts of America, Asia, and Europe, but extended to institutions in other cities and to such other subjects as gardens and music. Here we discuss only the Bliss impact on American archaeology.

In 1940, Mr. and Mrs. Bliss made the great gift of Dumbarton Oaks, their Washington home, to the Fogg Museum of Harvard University, together with its magnificent collections which chiefly represent Byzantine art. A short time previously, the Fogg Museum had decided to dismantle its aboriginal American hall in Cambridge. Hence the Bliss material from the New World was not included as part of the original gift but remained in the hands of an inveterate collector who proceeded to enlarge its scope and improve its quality. Only after his death was the collection transferred to Dumbarton Oaks, where it is to be shown permanently in a new wing which also contains his extensive library of Americana.

The Bliss interest in aboriginal America stemmed from the purchase in Paris in 1912 of one Olmec jade statuette - No. 8 in the published catalog. Curiously enough, neither he nor anyone else at that time could have said what it was, for the Olmec style was not identified until many years later, and its chronological position has been recognized even more recently. The collection grew very slowly, for it never was intended to represent any given area, period, or style; on the contrary, it reflected the personal taste of a discriminating individual.

In 1947, David E. Finley and John Walker, Director and Chief Curator, respectively, of the National Gallery of Art in Washington, suggested that the Bliss material be exhibited by that institution, where, in fact, it remained until his death. This was a bold decision, for no art museum in the United States maintained a comparable display at that time. It involved many problems of installation and lighting and the maintenance of guards in a location where attendance figures were in the hundreds of thousands annually.

When the Bliss collection went on public exhibition, the need for a published catalog became apparent. The late Alfred M. Tozzer sent the writer to do a job which was estimated to take less than a week. Needless to say, with the constant enlargement of the collection, it is not yet finished. In 1947 a small illustrated handbook was printed which sold out rapidly. In 1956, Bliss subsidized a much larger and more lavishly illustrated catalog. ${ }^{1}$ This was reissued in 1958 and is now out of print in English, but Italian and German editions are still available. Material for a second volume, a revised and enlarged edition, is in hand. If objects appear in one but not another of these catalogs, it is because they have been sold or traded.

The primary effect of the Bliss collection has been a wider acceptance of aboriginal American artifacts as art. The number of private collectors has multiplied greatly, and public interest is indicated by large attendance both in Europe and the United States at special loan exhibitions. Illustrated catalogs have been issued with many of these, and various large volumes on New World art have found a ready sale. Many of our major art museums now have entered the field with permanent exhibitions, including the arch-conservative Metropolitan Museum in New York, which recently has acquired a major example of Aztec sculpture. The older archaeological displays in university or natural history museums have been rejuvenated with improved installation and lighting, Some field archaeologists may deplore the trends here indicated; it is but fair to point out, however, that the funds for our work come from an interested public.

\footnotetext{
${ }^{1}$ Pre-Columbian Art. Robert Woods Bliss Collection. Text and critical analysis by S. K. Lothrop, W. F. Foshag, and Joy Mahler. Photography by Nickolas Muray. Phaidon Publishers Inc., London and New York.
} 
Certain aspects of the Bliss collection call for a word of comment. In the first place, he had little or no interest in New World pottery except Classical Maya and Teotihuacan; this autocatically eliminated styles which bulk large in other collections, such as Mixtec, Zapotec, and the western Mexican complex. Nor did he own such outstanding Peruvian wares as Chavin, Paracas, and Nazca. In general, the collection consists of relatively small objects, many of precious materials such as jade or gold. While some individual specimens have had a considerable history aboveground, basically this is an archaeological collection and there are only two objects known to have reached Europe in the 16 th century. One is a circular Aztec mirror of obsidian in its original wooden frame. Found in the flea market in Madrid, it was shattered in transit to Washington. The other is a lifesize Olmec mask of jade which was taken to Italy in the 1530's. Neither of these pieces has been published.

The Bliss interests in American archaeology were not limited to his own collection. He was a classmate and friend of Alfred M. Tozzer and a patron of the Peabody Museum of Harvard, which expects to publish soon the work he financed in Panama. In New York he served the American Museum of Natural History as trustee and, more recently, joined the board of the Museum of Primitive Art. In Washington, he was a trustee of the Carnegie Institution of Washington for many years. He visited the field projects at Chichen Itza and Uaxactun, and advocated a program at Tikal, which he had once reached on muleback. In addition, he was one of the two original sponsors of the Institute of Andean Research.

Robert Woods Bliss not only assembled a unique American collection, but he also helped to direct, or himself sponsored, a large amount of field research. To those who knew him, he will be remembered for his multiple interests, his unfailing courtesy and kindness, and his gift for friendship.

December, 1962 